\title{
The Stigma of Being "Haitian" in The Bahamas
}

\author{
William J. Fielding ${ }^{1}$, Virginia Ballance, Carol Scriven, \\ Thaddeus McDonald \& Pandora Johnson
}

\begin{abstract}
Haitian nationals have been migrating to and settling in The Bahamas for hundreds of years. However, the presence of Haitians in The Bahamas has been an ever-increasing cause for concern. In 1963, the Haitian community accounted for 3.2\% of the population; in 2000 it represented $7.1 \%$ and was numerically the largest migrant group in The Bahamas. The relatively high numbers of Haitian migrants on some Bahamian islands have raised fears that The Bahamas is being overwhelmed by this group; in some enumeration districts Haitian nationals account for more than $20 \%$ of the population. In common with migrant groups elsewhere, a stigma has become attached to being a Haitian migrant in The Bahamas. Primarily through the use of census data and newspaper articles, the paper attempts to explain this stigma. Haitian migrants are associated with illegal status, poor education, and poverty. Language is a barrier which prevents Haitian migrants from fully participating in society and makes them distinct from the general population. Children born in The Bahamas of migrants may face the prospect of being stateless. The paper stresses the need for the resident community to ensure that the stigma does not result in marginalisation and lead to a breakdown in relations between the Haitian and non-Haitian groups.
\end{abstract}

\section{INTRODUCTION}

Since their discovery by Columbus, the histories of The Bahamas and Haiti have been interwoven. The close geographical proximity of the two countries has been a source of "conflict and tensions, but also bringing mutual benefits" (Craton \& Saunders, 1998, p. 450). Economic links and trade flourished between the island nations throughout the $18^{\text {th }}$ century, resulting in many Haitian slave owners and their slaves establishing themselves in the Bahamian archipelago. Trade relations continued through the $19^{\text {th }}$ and early $20^{\text {th }}$ centuries with Haitian sloops plying the waters of the Bahamas trading salt, vegetables and livestock. It was not until the 1950s when the Bahamian economy became prosperous (with the rise in tourism) and the Haitian political situation deteriorated under Papa Doc, that greater numbers of Haitians, including some of the nation's educated classes, began migrating to The Bahamas in search of employment, giving rise to what became known as the "Haitian problem" (Marshall, 1979).

\footnotetext{
${ }^{1}$ William J. Fielding, Research, Planning and Development Office; Virginia Ballance, Libraries and Instructional Media Services; Carol Scriven, School of Business; Thaddeus McDonald, Faculty of Education \& Liberal Arts; Pandora Johnson, Research, Planning and Development Office all at The College of The Bahamas, Nassau, Bahamas.

W. J. Fielding is now in the Office of the President; Dr. Thaddeus McDonald is deceased; and Dr. Pandora Johnson is now Vice-President, Outreach.

Acknowledgments: This study formed part of a project on Haitian migrants in The Bahamas funded by the International Organization for Migration. The authors are grateful to the Census Unit of the Department of Statistics for producing the customised tables and Susan Plumridge for her comments on an earlier draft.

E-mail: wfielding@cob.edu.bs

How to cite this article in APA ( $5^{\text {th }}$ ed.) style: Fielding, W. J., Ballance, V., Scriven, C., McDonald, T., \& Johnson, P. (2008). The stigma of being "Haitian" in The Bahamas. The College of The Bahamas Research Journal, 14; 38-50. Retrieved from http://researchjournal.cob.edu.bs
} 
The size of the Haitian population resident in The Bahamas between the early 1970s and 1990s did not increase appreciably, because their migration was largely circular in nature. Many migrants would return to Haiti while others would move onward to the United States or Canada. However in the mid-1980s several factors increased public focus on the Haitian migrant population: there was a downturn in the Bahamian economy and less need for Haitian labour; internal political and economic chaos in Haiti following the departure of Duvalier in the mid 1980s saw an increase in the numbers of migrants fleeing Haiti and more Haitian migrants decided to settle in The Bahamas. With the increased visibility of the Haitian population in The Bahamas, in the 1990s, Haitian nationals were blamed for every social and medical ill imaginable: tuberculosis, cholera, AIDS, malaria, prostitution, drug dealing, theft, violent crime, gang warfare, etc. (Craton \& Saunders, 1998, p. 464). Despite their presence as an immigrant minority group in The Bahamas for over 50 years, the Haitian community remains little studied other than by Marshall (1979) and St. Jacques (2001).

Owing to the paucity of original survey research on the Haitian migrant population in The Bahamas, public opinion about and government responses to the migrant population may be tracked by reading reports in newspapers. There have been many complaints published in the newspapers, from both the public and government officials, that Haitian nationals are using health, education and social services at the expense and exclusion of Bahamians. A headline, such as "Haitians are a Drain on Sciety is the Overall Feeling of Bahamians" (Johnson, 2005) appears to reflect a typical public perception. However these perceptions invariability fail to stand scrutiny (St. Jacques, 2001; Stubbs, 1994; Bain, 2005). St. Jacques (2001) concluded that the "problem" was less about Haitian nationals using these services and more about Bahamian concerns regarding national and cultural sovereignty. Bahamians have been found to exhibit a strong sense of national self-identity and consequently are more inclined to exclude "outgroups" and exhibit xenophobic tendencies. Lightbourn (2000) studied Bahamian adolescents' nationalistic attitudes, concluding that they have anti-Haitian prejudices and would support harsher immigration policies as they perceive Haitians as a threat to their country.

Bahamian-born children of Haitian migrants appear to have been well assimilated, have obtained an education and for all intents and purposes are acculturated "Bahamians". However, according to the constitution of The Bahamas, they are not automatically conferred citizenship at birth, but must apply for citizenship between the ages of 18 and 19. The "Haitian problem" has therefore metamorphosed from one of uncontrolled migration to the government's reluctance to grant citizenship to "Haitian Bahamians" and the public's concerns about national self-definition (Craton \& Saunders, 1998). This concern has even greater implications as Bahamians of Haitian descent come of voting age, enter into the political arena or hold positions in institutions such as the police force.

The problems of Haiti which have recurred throughout its history and persist today include overpopulation, poor health, lack of education, bad agricultural management and deforestation (Leyburn, 1941). This background has resulted in the Republic of Haiti being regarded as a failed state (Gros, 1996) and may have resulted in Haitians elsewhere being stigmatised (Brodwin, 2001). Poor economic conditions, poverty and political instability have fuelled the migration of Haitians to many parts of the Caribbean (such as The Bahamas, Turks and Caicos Islands, Dominican Republic) and beyond as they search for employment (Ferguson, 2003).

Unlike other Caribbean societies which are a complex mixture of peoples, races, religions and ethnicities, the population of The Bahamas is more homogeneous, with nearly $96 \%$ of the population of African descent and 2.9\% of the population of Caucasian origin (Department of Statistics, 2002). In Guadeloupe, the Haitian population has suffered structural exclusion, symbolic denigration, economic and residential marginality, suspicion and stigma by the host society (Brodwin 2000, 2001, \& 2003). Like their counterparts in The Bahamas, migrant Haitians do 
not seek assimilation into the host society. Rather, migrant Haitian nationals forge a new identity by joining evangelical and Pentecostal churches (Brodwin, 2001). Transplanted Haitian nationals adopt a trans-national outlook. They revere their Haitian origins yet continue to live in an alien society while remaining apart from the dominant society (Brodwin, 2003). How these observations apply to the generation of foreignborn Haitians who are assimilated would be lines for future inquiry in the Bahamian and Guadeloupan contexts.

The literature cited above indicates that there may be a stigma attached to being "Haitian" in The Bahamas. This paper attempts to identify the characteristics of the Haitian community which can fuel a stigma. It draws primarily on data from the Bahamian Report of the 2000 Census of Population and Housing (2002) to compare the resident Haitian community with the non-Haitian community in The Bahamas as well as media reports about Haitian migrants to illustrate other aspects of "stigma".

\section{STIGMA}

The concept and definition of "stigma" was first elaborated by Goffman (1963). He found that stigma had three origins: physical deformities (and illnesses), blemishes of individual character, such as a weak will, and third, stigma of race, nationality or religion. A stigma is defined as "an attribute that is deeply discrediting", reducing the person "to a tainted, discounted one" (Goffman, 1963). Link and Phelan (2001) expanded on Goffman's original definition, identifying four interrelated components of stigma: (a) distinguishing and labelling differences (b) associating differences with negative attributes (c) separating "us" from "them" and (d) status loss and discrimination. These concepts will be used to demonstrate that a stigma is attached to being a Haitian national in The Bahamas.

\section{(a) Distinguishing and Labelling Human Differences}

The first component of Link and Phelan's typology is how humans distinguish and label differences between themselves and others. Depending on the situation, some differences are of no consequence or are trivial and easily overlooked. However, other differences are deemed to be socially salient and identified (or labelled).

Haitian and Bahamian nationals share a history of slavery and colonisation, as well as close trading ties in the first half of the $20^{\text {th }}$ century. Nonetheless, linguistic and cultural differences between the two nations create a barrier. The official language of the Bahamas is English and the official languages of the Republic of Haiti are French and Creole (kreyol). Language is therefore a distinguishing feature between Haitian migrants and Bahamians which easily allows the former to be labelled "Haitian". Many long-term Haitian residents who do not speak English fluently or with a Bahamian accent also set themselves apart from the mainstream society. In addition, many Bahamians claim to be able to distinguish Haitian nationals by their dress and physical appearance; however, we are unaware of any research which confirms these claims.

Lack of education is another major difference between Haitian migrants and others in The Bahamas. Within the Haitian community, males and females have broadly similar educational attainment. The most likely education level attained by Haitian nationals is either elementary or high school (Grades $1-3^{2}$ ), but about $12 \%$ have no schooling at all (see Table 1). It is clear that relatively few members of the Haitian migrant community have schooling beyond high school Grade $4^{3}$. This confirms the impression that the Haitian community is not particularly well educated.

\footnotetext{
${ }^{2}$ High school Grades 1-3: Junior High, Grades 7-9

${ }^{3}$ High school Grade 4+: Senior High, Grades 10-12.
} 
Table 1: Distribution of the Haitian population 15 years and over, by educational attainment and sex in The Bahamas

\begin{tabular}{|l|c|c|}
\hline Educational attainment & Males & Females \\
\hline No schooling & $10.3 \%$ & $14.8 \%$ \\
\hline Kindergarten & $0.6 \%$ & $0.5 \%$ \\
\hline Elementary & $29.3 \%$ & $28.7 \%$ \\
\hline High school, Grades 1-3 & $29.0 \%$ & $28.7 \%$ \\
\hline High school, Grades 4+ & $28.0 \%$ & $24.7 \%$ \\
\hline College & $1.9 \%$ & $1.6 \%$ \\
\hline Total & 8,596 & 5,322 \\
\hline $\begin{array}{l}\text { Note: From: Department of Statistics. (2002). Report of the } 2000 \\
\text { census of population \& housing. }\end{array}$ & \\
\hline
\end{tabular}

The level of education of the Haitian community contrasts with that of the rest of The Bahamas (see Table 2). For example: $42 \%$ of Haitian nationals and $8 \%$ of non-Haitians failed to obtain a high school education or more (Department of Statistics, 2002).

Table 2: Distribution of the populations of Haitian and nonHaitian nationals over 15 by not attending school and educational attainment in The Bahamas

\begin{tabular}{|l|c|c|}
\hline $\begin{array}{l}\text { Highest educational } \\
\text { attainment }\end{array}$ & $\begin{array}{c}\text { Non-Haitian } \\
\text { households }\end{array}$ & $\begin{array}{c}\text { Haitian } \\
\text { households }\end{array}$ \\
\hline No schooling & $0.7 \%$ & $12.2 \%$ \\
\hline Kindergarten & $0.1 \%$ & $0.6 \%$ \\
\hline Elementary & $7.1 \%$ & $29.4 \%$ \\
\hline High School, Grade 1-3 & $19.3 \%$ & $29.2 \%$ \\
\hline High School, Grade 4+ & $56.1 \%$ & $27.0 \%$ \\
\hline College or higher & $16.7 \%$ & $1.8 \%$ \\
\hline Total & 172,751 & 13,775 \\
\hline
\end{tabular}

Note: from: Department of Statistics. (2002). Report of the 2000 census of population \& housing

The Student Nationality Report (Bain, 2005) gives an overview of student numbers by nationality in early 2005, which referred to about $75 \%$ of the total school enrolment. That study indicated that about $9 \%$ of the entire student population attending private and public schools were Haitian nationals. In the publicly-funded government school system, about $11 \%$ of students were Haitian nationals. Except for the islands of Abaco and New Providence, the enrolment of Haitian children by island indicates a proportion in keeping with the relative size of the Haitian communities (see Table 3).

\begin{tabular}{|c|c|c|}
\hline \multicolumn{3}{|c|}{$\begin{array}{c}\text { Table 3: Percentage of the general population and } \\
\text { percentage of school students who were Haitian in The } \\
\text { Bahamas }\end{array}$} \\
\hline Island & $\begin{array}{l}\% \text { of Haitian } \\
\text { nationals in } \\
\text { general population }\end{array}$ & $\begin{array}{l}\% \text { of Haitian } \\
\text { students in } \\
\text { Government } \\
\text { schools }\end{array}$ \\
\hline Abaco & $16.9 \%$ & $31.3 \%$ \\
\hline New Providence & $7.2 \%$ & $12.5 \%$ \\
\hline Grand Bahama & $5.4 \%$ & $5.8 \%$ \\
\hline Eleuthera & $9.5 \%$ & $10.0 \%$ \\
\hline \multicolumn{3}{|c|}{$\begin{array}{l}\text { Note: From: Bain, B. (2005). Student nationality report. Nassau: } \\
\text { Ministry of Education, Planning and Research Section) \& epartment } \\
\text { of Statistics. (2002). Report of the } 2000 \text { census of population \& } \\
\text { housing. }\end{array}$} \\
\hline \multicolumn{3}{|c|}{$\begin{array}{l}\text { The nature of the employment undertaken by } \\
\text { Haitian nationals, which may be a result of their } \\
\text { poor education and language skills, again } \\
\text { distinguishes them from other communities within } \\
\text { the country. The reported occupations of the } \\
\text { Haitian community in the } 2000 \text { census explain } \\
\text { why Haitian households have some of the lowest } \\
\text { household incomes in The Bahamas and why } \\
\text { Haitian households occupy a disproportionate } \\
\text { place in the number of households in poverty. } \\
\text { The } 2000 \text { census placed over } 80 \% \text { of employed } \\
\text { Haitian nationals in elementary occupations } \\
\text { whereas only about } 47 \% \text { of non-Haitians are } \\
\text { employed in the same occupations (see Table } 4 \text { ). }\end{array}$} \\
\hline
\end{tabular}

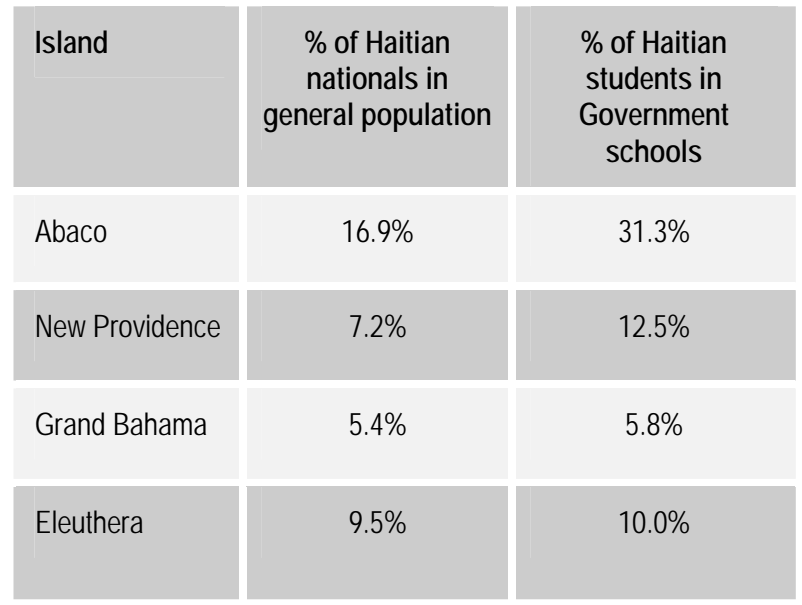

Note: From: Bain, B. (2005). Student nationality report. Nassau: of Statistics. (2002). Report of the 2000 census of population \&

The nature of the employment undertaken by Haitian nationals, which may be a result of their poor education and language skills, again distinguishes them from other communities within the country. The reported occupations of the Haitian community in the 2000 census explain why Haitian households have some of the lowest household incomes in The Bahamas and why Haitian households occupy a disproportionate place in the number of households in poverty. The 2000 census placed over $80 \%$ of employed whereas only about $47 \%$ of non-Haitians are employed in the same occupations (see Table 4). 
Table 4: Haitian nationals employed by industrial group in The Bahamas

\begin{tabular}{|c|c|c|}
\hline & Non-Haitian nationals & Haitian nationals \\
\hline Private households with employed persons & $3.2 \%$ & $25.2 \%$ \\
\hline Construction & $10.8 \%$ & $23.2 \%$ \\
\hline Agriculture & $0.9 \%$ & $13.5 \%$ \\
\hline Wholesale, retail trade, repair & $15.0 \%$ & $11.9 \%$ \\
\hline Hotels \& restaurants & $17.7 \%$ & $10.9 \%$ \\
\hline Manufacturing & $4.2 \%$ & $4.2 \%$ \\
\hline Real estate, renting & $5.3 \%$ & $3.6 \%$ \\
\hline Other community, social and personal service & $6.0 \%$ & $2.8 \%$ \\
\hline Transport, storage, communication & $7.7 \%$ & $1.7 \%$ \\
\hline Education & $6.2 \%$ & $0.9 \%$ \\
\hline Fishing & $1.8 \%$ & $0.8 \%$ \\
\hline Health \& social work & $3.9 \%$ & $0.3 \%$ \\
\hline Public Administration & $9.5 \%$ & $0.3 \%$ \\
\hline Financial intermediation & $6.0 \%$ & $0.2 \%$ \\
\hline Electricity, gas \& water & $1.3 \%$ & $0.1 \%$ \\
\hline Extra-territorial organizations & $0.2 \%$ & $0.1 \%$ \\
\hline Mining & $0.3 \%$ & $0.1 \%$ \\
\hline Total & 146,654 & 9,474 \\
\hline
\end{tabular}

Note: From: Department of Statistics. (2002). Report of the 2000 census of population \& housing

In addition to being employed in lower-income occupations, the Haitian community suffers from a higher rate of unemployment $(11.2 \%$ of 10,728 persons) than non-Haitian nationals $(4.2 \%$ of 143,668 persons) in the economically active population over 15 years of age (Department of
Statistics, 2002). Employment in low-skilled manual occupations results in Haitian nationals earning less than non-Haitians. Median annual income of employed persons over 15 years was \$8,253 for Haitian nationals and \$26,925 for nonHaitian nationals (Department of Statistics, 2002). 
Poverty of Haitian migrants emerges as another feature which distinguishes them from the rest of the community (Department of Statistics, 2004). Table 5 illustrates the differences in the household income of the Haitian community between islands. It should also be noted that for a household of four persons the poverty line is $\$ 11,452$ and therefore the census findings are in line with the observation that many Haitian households live in poverty (Department of Statistics, 2004).

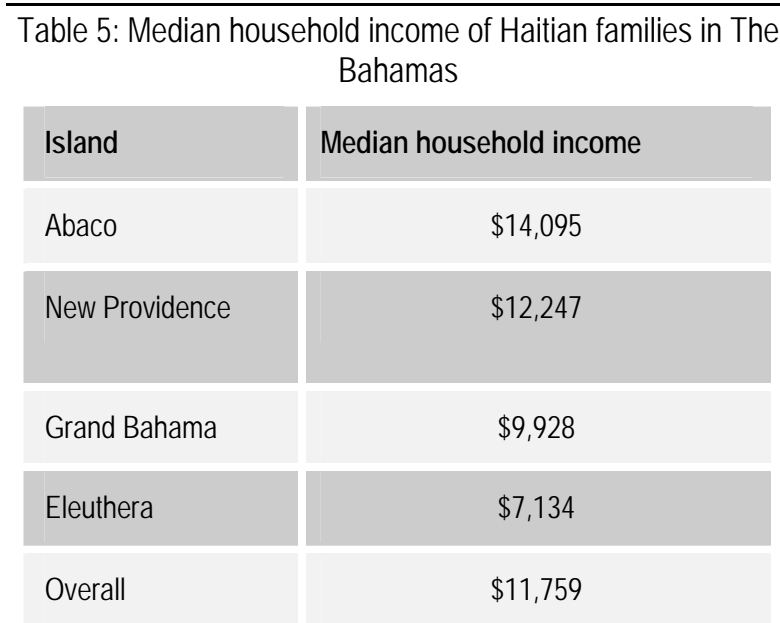

Note: From: Department of Statistics. (2002). Report of the 2000 census of population \& housing

Poor English-language ability, lower levels of educational achievement, poverty and unemployment are all stigmatizing differences between the Haitian migrant population and the native Bahamian population.

\section{b) Associating Human Differences with Negative Attributes}

Link and Phelan's second component of stigma links labelled differences to stereotypes, with the "label linking a person to a set of undesirable characteristics that form the stereotype" (p. 369). The conveyed identity is therefore devalued, or stigmatized.

Several perceptions associated with the Haitian community relate to their stereotyped negative characteristics-Haitian nationals do not get married, they live together, they have too many children, they take jobs away from Bahamians. In a country where family ties and structure are important, such perceptions can elicit rejecting responses from the dominant population about outside groups.

The Haitian community may have a looser family structure than the non-Haitian community, with disproportionately more common-law relationships (Table 6). Haitian nationals aged 20 or over were less likely to be married and more likely to be single or in a common-law relationship than those from other communities. Given that employment is the driving force behind their migration, the lower percentage of Haitian nationals in formal unions would be expected as economic instability does not encourage permanent relationships. In an overtly Christian country such as The Bahamas where common-law unions are not prevalent, such relationships may be considered "ungodly" or against the teachings of the Bible and people in such relationships fall outside mainstream society.

Table 6: Marital status of the Haitian and non-Haitian communities in The Bahamas

\begin{tabular}{|l|c|c|}
\hline & Non-Haitian households & Haitian households \\
\hline Married & $43.1 \%$ & $37.3 \%$ \\
\hline Single & $26.1 \%$ & $32.5 \%$ \\
\hline Common-law & $7.4 \%$ & $21.5 \%$ \\
\hline Separated & $7.0 \%$ & $5.0 \%$ \\
\hline Widowed & $9.2 \%$ & $3.1 \%$ \\
\hline Divorced & $7.3 \%$ & $0.7 \%$ \\
\hline Total & 81,013 & 6,450 \\
\hline
\end{tabular}

Note: From: Department of Statistics. (2002). Report of the 2000 census of population \& housing

Haitians are perceived to have a large number of children and consequently large households. While overall, the 2000 census data does not support the latter perception, (14\% of Haitian households include six or more persons compared to $15 \%$ in the non-Haitian households, Department of Statistics, 2000), these 909 households may be sufficiently numerous to invite comment from those outside of the Haitian community. However, the number of registered 
live births between 1995 and 2004 clearly indicates that the Haitian community is producing disproportionately more babies than the Bahamian community (Figure 1). The data indicate that while Haitians make up about $7 \%$ of the population of The Bahamas, babies born to
Haitian mothers have accounted for almost 14\% of live births in recent years. This observation may be the cause of the fear that Haitians will "take over" the country and be the cause of immigration concerns with respect to the fate of these Bahamian-born children.

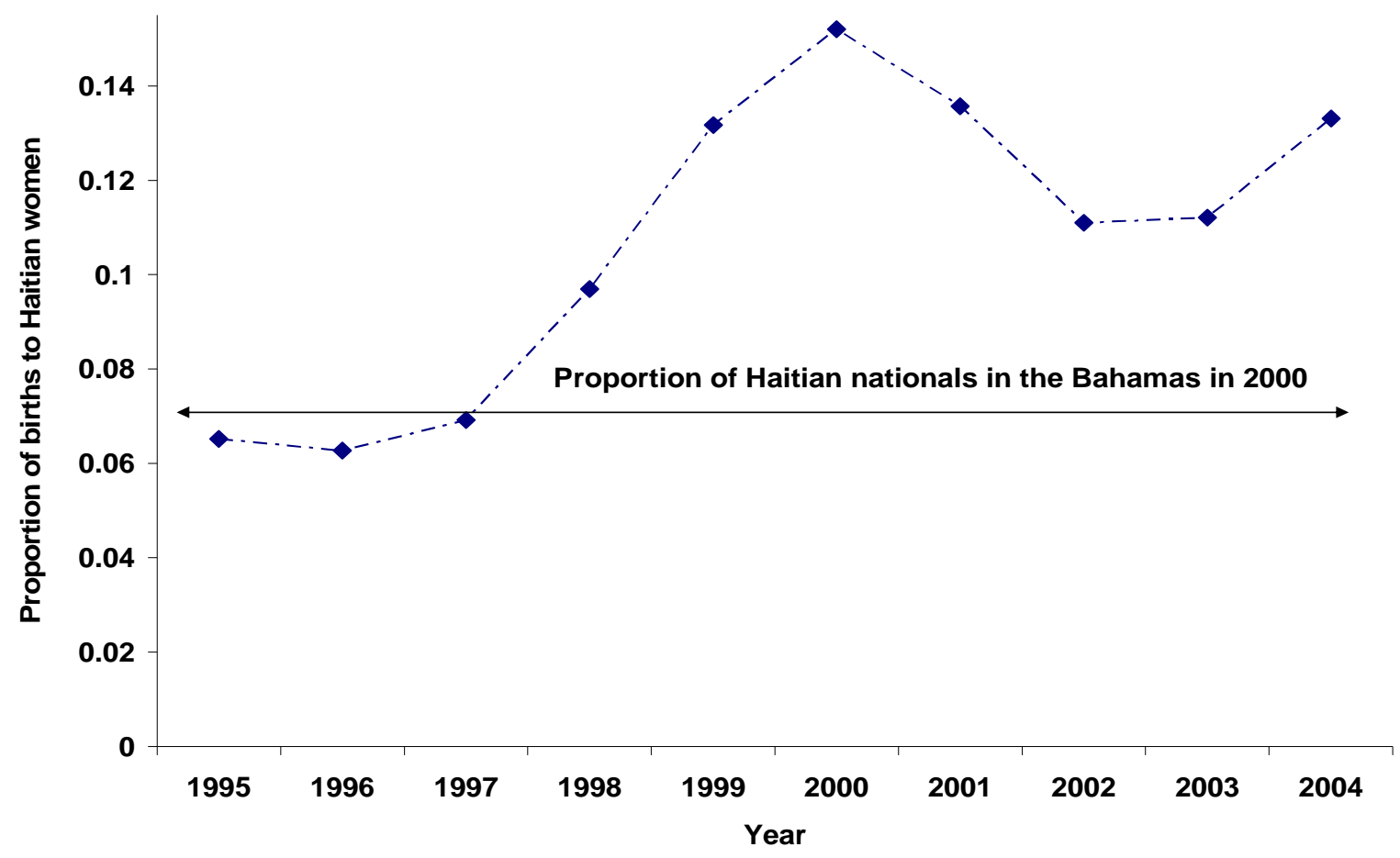

Figure 1: Proportion of live births in The Bahamas to Haitian women, 1995-2004. Note: From: Vital Statistics Section, Department of Statistics, undated.

The Haitian community had a median age of 24.5 years whereas the non-Haitian community had a median age of 17.1 years (Department of Statistics, 2004). This indicates that the Haitian community is generally older. This observation confirms that the Haitian community's primary motivation is probably to find employment. In times of economic restraint and unemployment this can generate fears that migrants are taking jobs from nationals. This is illustrated by newspaper reports, such as that by Lightbourne (2005), of vendors at the Straw Market in central Nassau complaining that ethnic Haitians outnumber native Bahamians.
Clearly, some of these perceptions are supported by the figures, but the data may mask more complex negative imprinting.

\section{c) Separating "Us" From "Them"}

The third component involves the separation of "us" and "them". The dominant society will isolate the "outgroup", who, because they have been labelled with undesirable characteristics can have bad characteristics attributed to "them" with impunity. Particularly salient is that the Bahamian public has come to regard all Haitian nationals as illegal immigrants, regardless of their legal status. Separation of "us" and "them" occurs on a clear physical basis in addition to other ways. 
The fact that Bahamians distinguish themselves from Haitian migrants has probably arisen because of the increase in the relative size of the Haitian community within The Bahamas.

In 2000, the population of The Bahamas included foreign nationals from over 64 countries, accounting for $12.7 \%$ of the population. Of this group, Haitian nationals accounted for $56 \%$ (of 38,454 persons). This fact helps to explain why the Haitian community has received so much more attention in the press than other communities such as the Jamaican, Cuban or Chinese (nationalities which may include illegal migrants).

During the period 1963 to 2000, the size of the resident Haitian community increased from 4,170 to 21,426 , which represents a decennial increase of approximately $40 \%$ from one census to the next (see Table 7). The relative size of the Haitian community in The Bahamas population increased from $3.2 \%$ (in 1963) to $7.1 \%$ (in 2000), so the size of the resident Haitian community has been increasing above that of the overall increase in the population of The Bahamas (see Table 7). It is this disproportionate increase in the size of the Haitian community which could be the basis for the call to "send them home" ("An Eye Opener", 2005).

\begin{tabular}{|c|c|c|c|}
\hline \multicolumn{4}{|c|}{$\begin{array}{l}\text { Table 7: Population counts for the resident Haitian } \\
\text { community and the entire population in The Bahamas }\end{array}$} \\
\hline Year & Haitian nationals & All Bahamas & $\%$ of population \\
\hline & & & Haitian nationals \\
\hline 1963 & 4,170 & 130,220 & $3.2 \%$ \\
\hline 1970 & 6,151 & 168,812 & $3.6 \%$ \\
\hline 1980 & 10,337 & 209,505 & $4.9 \%$ \\
\hline 1990 & 16,567 & 255,049 & $6.5 \%$ \\
\hline 2000 & 21,426 & 303,611 & $7.1 \%$ \\
\hline
\end{tabular}

Note: From: Department of Statistics. (2002). Report of the 2000 census of population \& housing

The Haitian community in 2000 was primarily concentrated in just four islands of The Bahamas: New Providence, Grand Bahama, Abaco and Eleuthera. Within each of these islands the census data indicate that there are relatively few pockets where the Haitian community makes up more than $10 \%$ of an enumeration district (see Table 8). However, in the small populations of Abaco and Eleuthera, the presence of even a few Haitian migrants can have a big impact on the mix of these communities. Consequently, it is not surprising that many media reports and letters to editors relate to Haitian migrants in Abaco (Bonimy, 2005).

\begin{tabular}{|c|c|c|c|c|c|c|}
\hline \multirow[b]{3}{*}{ Island } & \multicolumn{6}{|c|}{ Table 8: Relative size of the Haitian community in enumeration districts in The Bahamas } \\
\hline & \multirow[b]{2}{*}{$\begin{array}{l}\text { Number of } \\
\text { Haitian nationals }\end{array}$} & \multicolumn{4}{|c|}{$\begin{array}{l}\text { Percentage of enumeration districts in which the Haitian community } \\
\text { accounted for selected percentages of the population }\end{array}$} & \multirow{2}{*}{$\begin{array}{c}\begin{array}{c}\text { No. of } \\
\text { enumeration } \\
\text { districts }\end{array} \\
\text { N }\end{array}$} \\
\hline & & $<5 \%$ & $5-10 \%$ & $11-20 \%$ & $>20 \%$ & \\
\hline New Providence & 15,201 & $45.8 \%$ & $33.3 \%$ & $16.7 \%$ & $4.2 \%$ & 24 \\
\hline Grand Bahama & 2,550 & $66.7 \%$ & $16.7 \%$ & $16.7 \%$ & $0.0 \%$ & 6 \\
\hline Abaco & 2,229 & $0.0 \%$ & $50.0 \%$ & $0.0 \%$ & $50.0 \%$ & 2 \\
\hline Eleuthera & 1,069 & $0.0 \%$ & $50.0 \%$ & $50.0 \%$ & $0.0 \%$ & 4 \\
\hline All other districts & 387 & $100.0 \%$ & $0.0 \%$ & $0.0 \%$ & $0.0 \%$ & 15 \\
\hline
\end{tabular}


Spatial separation and additional separations based on income combine to distinguish Haitian migrants from other communities. Most Haitian households (75\%) live in rented accommodation compared to $33 \%$ in the non-Haitian community. The median rent or mortgage paid per month was \$162. When compared with \$251 for all other residents, this indicates that Haitians live in cheaper and undoubtedly lower-standard accommodation than others in the country.

Access to potable water by Haitian households again indicates that their level of accommodation is poorer than that for others in the country. Of 6,469 Haitian households in the census, only 34\% had public water piped into their homes, and $28 \%$ used public standpipes; a further $16 \%$ had access to a private water supply which was not piped into their homes (see Table 9).

Table 9: Main source of water supply for private Haitian and non-Haitian homes in The Bahamas

\begin{tabular}{|l|c|c|}
\hline & $\begin{array}{c}\text { Non-Haitian } \\
\text { households }\end{array}$ & $\begin{array}{c}\text { Haitian } \\
\text { households }\end{array}$ \\
\hline Public piped into dwelling & $57.6 \%$ & $34.0 \%$ \\
\hline Public standpipe & $3.7 \%$ & $27.5 \%$ \\
\hline Private not piped & $2.3 \%$ & $15.5 \%$ \\
\hline Private piped into dwelling & $32.2 \%$ & $10.2 \%$ \\
\hline Public piped into yard & $1.7 \%$ & $7.0 \%$ \\
\hline Other & $0.7 \%$ & $2.6 \%$ \\
\hline Public well or tank & $0.6 \%$ & $2.1 \%$ \\
\hline Rain water system & $1.3 \%$ & $1.0 \%$ \\
\hline Total number of households & 81,223 & 6,469 \\
\hline
\end{tabular}

Note: From: Department of Statistics. (2002). Report of the 2000 census of population \& housing

In addition to having poorer access to water, Haitian households have poorer toilet facilities than other residents: $38.5 \%$ (of 6,457 ) of Haitian households shared a toilet compared with $4.8 \%$ (of 80,123) of non-Haitian households. The frequency of selected amenities found in Haitian households is given in Table 10 . Haitian households were less likely than the wider public to have any of the items.

Table 10: Presence of amenities in all households in The Bahamas and in Haitian households in The Bahamas.

\begin{tabular}{|l|c|c|}
\hline Item & $\begin{array}{c}\text { \% of non-Haitian } \\
\text { households having }\end{array}$ & $\begin{array}{c}\text { \% of Haitian } \\
\text { households having }\end{array}$ \\
\hline Television & $95.3 \%$ & $64.4 \%$ \\
\hline Water heater & $74.3 \%$ & $13.7 \%$ \\
\hline $\begin{array}{l}\text { Air } \\
\text { conditioning }\end{array}$ & $57.5 \%$ & $6.1 \%$ \\
\hline $\begin{array}{l}\text { Access to } \\
\text { computer }\end{array}$ & $30.0 \%$ & $1.2 \%$ \\
\hline $\begin{array}{l}\text { Internet } \\
\text { Total of } \\
\text { households }\end{array}$ & $16.6 \%$ & $0.4 \%$ \\
\hline
\end{tabular}

Note: From: Department of Statistics. (2002). Report of the 2000 census of population \& housing

Another distinction between the Haitian and nonHaitian communities is the rate of HIV/AIDS and tuberculosis. There is considerable stigma, shame and denial surrounding the subject of HIV/AIDS throughout the Caribbean, including The Bahamas. The Republic of Haiti suffers from a well publicised HIV/AIDS epidemic with an even higher infection rate than The Bahamas (Inciardi, Syvertsen, \& Surratt, 2005). Thus it is not surprising that the Haitian community in The Bahamas also has a high HIV/AIDS rate (Brathwaite, Brathwaite, Pratt \& Brathwaite, 2002). The emotive nature of the disease also serves to set the Haitian community apart.

\section{d) Status Loss and Discrimination}

The fourth component of stigma includes status loss and discrimination. Labelling, being set apart and linked to undesirable characteristics leads persons to experience status loss and discrimination (Link \& Phelan, 2001, p. 371).

Due to the unregulated pattern of migration between The Republic of Haiti and The Bahamas one can assume that migrants either arrive illegally or overstay their visitors' visas, and become illegal as a result. After obtaining work, 
many migrants then try to secure work permits to legalise their employment and residence status in The Bahamas. However, the migrants' lack of work permits or status allows them to be exploited by employers or other persons in authority.

Structural and individual discrimination characterize the stigma of Haitian migrants. The granting of Bahamian citizenship exemplifies structural discrimination against children born to non-Bahamian parents. Citizenship is not automatically conferred on children born in the country. Children born in The Bahamas to nonBahamian parents may only apply to become a naturalized Bahamian citizen at age eighteen. While it may be possible for a child born to Haitian parents in The Bahamas to apply for a Haitian passport, they might not do so because they do not wish to jeopardise their future claim to Bahamian citizenship, or because they identify more strongly with The Bahamas, their birth place, than Haiti, the land of their parents. Consequently, until age 18 they are considered "stateless" (Ferguson, 2003). A passport is commonly used as an identification document in The Bahamas; without it, one cannot open a bank account, travel abroad or fully participate in the activities of mainstream society. "Stateless" children may be treated as foreigners and charged higher rates than Bahamians for the same services, for example tuition fees at the local college (Eugene, 2004).

Surnames can be an indicator of ethnicity and used to label and discriminate (Dooley, 2004). In the case of Haitian surnames, history has blurred this distinction because some surnames accepted as "Bahamian" are of Haitian origin (McWeeney, 1994). However, there are stories of Haitian migrants either changing or falsifying their names in order to avoid discrimination. Claims of discrimination (Vedrine, 2005) and abuse (Eugene, 2004) against ethnic Haitians appear regularly in the press which may suggest that many in this community may be suffering insults as a result of their ethnicity, or at least endure conversations which "attack Haitians" (Johnson,

*As of fall 2008, all new students of The College of The Bahamas will pay Bahamian tuition rates provided they have completed at least 6 years of high school in The Bahamas. (Ed.)
2006). These reports contrast with the official position that there is no discrimination against foreigners (Thompson, 2005).

The poverty of the Haitian community results in its having to rely on essentially "free" government services such as education and health. While there is no evidence that members of Haitian households are any more or less likely to have to use a health facility than Bahamian households, when they do need health care they are 1.8 times more likely than Bahamian households to attend a government health facility (Department of Statistics, 2004). This results in a concentration of Haitian nationals in government health facilities which has encouraged the public perception that the Haitian population is taking over and make use of facilities designed for Bahamians.

The result of all this is that Bahamians have long 'looked-down' on Haitians as not being social equals (Small, 2004).

\section{DISCUSSION}

This comparison of the Haitian and non-Haitian communities confirms many of the stereotypes and perceptions associated with the Haitian community. It is clear that the Haitian community lives in poorer circumstances than other residents in the country. Almost certainly this is due to lower incomes, which in turn is a result of poor education and (presumably) language barriers, which prevent Haitian nationals from gaining better-paid employment. If workers arrive in the country illegally, as is often the case, they run the risk of being paid "cheap" wages (Lightbourne, 2005). The higher level of unemployment within the Haitian community means that an already poor community will probably have to support its unemployed members as they might not wish to or cannot avail themselves of state-provided social services because of their illegal status. Thus it can be seen that a vicious cycle of low wages and unemployment ensures the continued poverty of the Haitian community. This poverty has been noted in The Bahamas Living Conditions Survey 2001 (Department of Statistics, 2004), as well as in the lower average household income found in Haitian homes. Consequently, their poverty attracts the stigma associated with being poor 
(Waxman, 1977).

Poverty obliges Haitian nationals to live in poorer accommodation than non-Haitian nationals. They live in poorly built and poorly maintained houses which are less likely to have the basic amenities, let alone modern electrical appliances. In some instances, the lack of appliances may result from the lack of electricity in the home. Their poor accommodation is a clear manifestation of their poverty. The lack of access to running water or a water heater can be expected to reduce personal hygiene standards and the ability of householders to clean clothes etc. to the standard expected by the majority of society. The poor sanitary conditions can then lead to the idea that the migrants are "dirty" or "unclean" which adds further to their isolation and stigmatisation.

The census data show that there has been a steady increase in the size of the Haitian community since 1963, with a surge in size from the 1980s onward. The fact that the Haitian community is not evenly spread throughout the country means that its presence can be keenly felt in some areas, particularly where the national population is small, such as certain neighbourhoods in New Providence or on the islands of Abaco and Grand Bahama. This has resulted in a perception that the Haitians are taking over. It would seem that economic opportunities are the driving force which causes the Haitian community to become concentrated, which would be expected given that Haitians migrate to The Bahamas to find work. The disproportionate increase in the size of this Haitian community can be expected to make nationals feel threatened, and lead to xenophobia and, in the case of the Dominican Republic, to attacks on Haitian migrants (Harman, 2006).

Haitian nationals clearly bring less education with them to the workforce than non-Haitian nationals. The lack of education, technical skills and English literacy, forces Haitian nationals to accept poorly paid manual work. The poor pay, which may be less than that received by other nationals again contributes to the poverty of the Haitian community. In addition, migrant labourers are usually expected to pay for their annual work permits and National Insurance contributions. Frequently the migrant might be expected to pay someone to assist them in acquiring the work permit, placing an extra burden on an already low income. The number of Haitian nationals competing for manual work has resulted in higher unemployment in the Haitian than non-Haitian community. The result of unemployment is that this already poor community must stretch its resources to support non-earning members resulting in further reduction of its quality of life. Additionally, the lack of education and English fluency brings its own stigma, a stigma of being considered stupid or less than others in society. Recent migrants to The Bahamas speak English with a distinct accent, which also sets them apart. The accent is mocked in radio and television advertisements. The type of employment taken by Haitian nationals, predominantly low-skilled work in gardening, construction and restaurants, has resulted in certain classes of work being referred to as "Haitian" work.

The obligations of governments to provide education for all children within a country are set out in the United Nations Convention on the Rights of the Child (http://www.unicef.org/crc/). Taylor (2005) addressed issues surrounding the education needs of Haitian children, suggesting that the Bahamian government may not be able to provide all the resources required to meet these responsibilities. The percentage of places occupied in public schools by children of Haitian origin indicates that in some communities these children could be considered as consuming a substantial part of the resources provided for education. However, it should be noted that while many adult Haitian nationals may themselves lack education, they wish to ensure that their children benefit from a better education than their own. Taylor notes some specific needs of Haitian students which government should provide, such as teaching English as a second language and skills training for older students. While the nonHaitian community may complain that the children of Haitian migrants are occupying many places in schools, it is in the best interest of the country to educate rather than marginalize them. Clearly if Bahamian-born children of Haitian migrants are not educated and allowed to participate in Bahamian society, there is the risk that structural discrimination and marginalization will lead to continued stigmatization of Haitians. 
Overlying the characteristics which can be identified from the 2000 census as contributing to the stigma of being "Haitian" in The Bahamas (lack of education, menial employment, substandard housing, living in ghetto-type concentrations with limited access to sanitation and running water) are those of illegal status and being carriers of HIV (Brathwaite, et al., 2002). These last, less well-quantified aspects combine to further set the Haitian community apart from others in The Bahamas. All these aspects of the stigma of being Haitian will need prolonged education of the public to dismantle the prejudices which can develop towards a disadvantaged group. It will also require the government to take steps to integrate Haitian nationals into Bahamian society through education, thereby removing structural discrimination. Rather than being considered a threat, as migrants can be, these people should be seen as a legitimate part of a multicultural society who enrich the lives of all residents.

\section{REFERENCES}

Bain, B. (2005). Student nationality report. Nassau: Ministry of Education, Planning and Research Section.

Bonimy, J. (2005, October 6). Violent prediction for Abaco shantytowns. The Nassau Guardian. Retrieved from http://archive.nassauguardian.net.

Brathwaite, A. F., Brathwaite, V., Pratt, C., \& Brathwaite, N. (2002). HIV infections in Grand Bahama, 1991-1995: A comparative analysis with 1985-1990. Bahamas Journal of Science 10 (1), 2329.

Brodwin, P. (2000). Pentecostalism and the production of community in the Haitian Diaspora. Retrieved from University of Wisconsin Milwaukee Web site: http://www.uwm.edu/Dept/CLACS/resources/pubs/p df/brodwin90.pdf

Brodwin, P. (2001). Marginality and cultural intimacy in a transnational Haitian community. Retrieved from University of Wisconsin Milwaulkee Web site: http://www.uwm.edu/Dept/CLACS/resources/pubs/p df/brodwin91.pdf

Brodwin, P. (2003). Pentecostalism in translation: Religion and the production of community in the Haitian Diaspora. American Ethnologist, 30(1). 85101.

Craton, M., \& Saunders, G. (1998). “The Bahamian self and the Haitian other: The history of Haitian migration". In Islanders in the stream: A history of the Bahamian people, vol. 2. From the ending of slavery to the twenty-first century. (pp. 450-469) Athens: University of Georgia Press.

Department of Statistics. (2002). Report of the 2000 census of population \& housing. Nassau, Bahamas: Author.
Department of Statistics. (2004). Bahamas living conditions survey, 2001. Nassau, Bahamas: Author.

Dooley, B. (2004, October 4). Your name could put you in jail. New Statesman. p. 17. Retrieved from http://www.newstatesman.com/200410040009.

Eugene, D. (2004, February 9). The plight of children born to Haitian parents in The Bahamas. The Tribune, p. 3A.

An eye opener [Editorial]. (2005, August 19). The Nassau Guardian. Retrieved from: http://archive.nassauguardian.net.

Ferguson, J. (2003). Migration in the Caribbean: Haiti, the Dominican Republic and beyond. Retrieved from the Minority Rights Group International Web site: http://www.minorityrights.org/admin/download/pdf/ MRGCaribbeanReport.pdf

Goffman, E. (1963). Stigma: Notes on the management of spoiled identity. Englewood Cliffs, N.J.: Prentice Hall.

Gros, J. (1996). Towards a taxonomy of failed states in the New World Order: Decaying Somalia, Liberia, Rwanda and Haiti. Third World Quarterly 7(3), 455472. Retrieved from EbscoHost Academic Search Complete database.

The Haitian problem [Editorial]. (2005, February 8). The Nassau Guardian. Retrieved from: http://archive.nassauguardian.net.

Harman, D. (2006). Haitian migrants face raising backlash next door. Christian Science Monitor, 98(40), p. 4. Retrieved from EbscoHost Academic Search Complete database.

Inciardi, J. A., Syvertsen, J. L., \& Surratt, H. L. (2005). HIV/AIDS in the Caribbean basin. AIDS Care, 17 (Supplement 1), 9-25.doi: 


\subsection{0/09540120500120955.}

Johnson, C. (2005, March 3). "Haitians are drain on society is overall feeling of Bahamians". The Tribune, pp. 1C-2C.

Johnson, C. (2006, February 9). "I don’t want you to sit next to me with your Haitian self". The Tribune, pp. 1C, 6C.

Leyburn, J. C. (1941). The Haitian people. New Haven: Yale University Press.

Lightbourn, T. J. (2000). When diasporas discriminate: Idenity choices and anti-immigrant sentiment in the Bahamas (Doctoral dissertation, University of Michigan, 2000). Dissertation Abstracts International, 61, 1698.

Lightbourne, K. (2005, September 9). Market illegals return to work. The Nassau Guardian. Retrieved from http://archive.nassauguardian.net.

Link, B. G., \& Phelan, J. C. (2001). Conceptualising stigma. Annual Review of Sociology 27, 363-85. Retrieved from EbscoHost Academic Search Complete database.

Marshall, D. I. (1979). 'The Haitian problem': Illegal migration to the Bahamas. Kingston, Jamaica: Institute of Social and Economic Research, University of the West Indies.

McWeeney, S. (1994). The "Haitian problem" in the Bahamas at the close of the eighteenth century. Journal of the Bahamas Historical Society 16, 2-9.
St. Jacques, E. (2001). Today Haitians, tomorrow Bahamians: Reassessing the integration of Haitian immigrants in the Bahamas. Unpublished master's thesis, University of Florida.

Small, M. (2004, August 26). Examining the impact of not belonging to any country. The Nassau Guardian. Retrieved from http://archive.nassauguardian.net.

Stubbs, E. (1994). The Impact of Haitian students on educational cost in Ministry schools within the Commonwealth of the Bahamas, 1991. Nassau: Ministry of Education.

Taylor, M. C. (2005). Education for all: Addressing the educational needs of Haitians in the Bahamas. In Ministry of Education, $18^{\text {th }}$ national education conference: Transforming Bahamian education for the $21^{\text {st }}$ century (pp. 16-21). Nassau: Ministry of Education.

Thompson, L. (2005, September 15). Immigrants get equal health care. The Nassau Guardian. Retrieved from http://archive.nassauguardian.net.

Vedrine, B. (2005, August 23). Trying to fit in: Growing up in the Bahamas with Haitian parents. The Nassau Guardian. Retrieved from http://archive.nassauguardian.net.

Waxman, C. J. (1977). The stigma of poverty. New York: Pergamon. 